ІСТОРІОГРАФІЯ ПИТАННЯ ПРОФЕСІЙНОЇ ПІДГОТОВКИ МОЛОДІ ПЕРШОЇ ХВИЛІ УКРАЇНСЬКОЇ ЕМІГРАЦІЇ (КІНЕЦЬ XІХ - ПОЧАТОК ХХ СТОЛІТТЯ)

\title{
HISTORIOGRAPHY OF THE QUESTION OF PROFESSIONAL PREPARATION FOR THE YOUNG PEOPLE OF THE FIRST WAVE OF UKRAINIAN EMIGRATION (END OF XIX - EARLY XX CENTURY)
}

\begin{abstract}
У статті здійснено історіографрічний аналіз питання профресійної підготовки молоді першої хвилі української еміграції в контексті розвитку українського икільництва кінця XIX - початку XX cm., досліджено й систематизовано джерельну базу означеного періоду.

Опираючись на першоджерела та періодику держав потенційного поселення українцівемігрантів, наукові розвідки вчених України та української діаспори, проаналізували зміст досліджень, наукової літератури, першоджерел, присвячених першій хвилі української еміграції в контексті усталеної хронології, територіальних меж, ступеня розкриття в джерелах «материкової» України й українського зарубіжжя.
\end{abstract}

здійснено поділ змісту матеріалів періодичних видань перших десятиліть $X X \mathrm{~cm}$., які становлять вагому частину джерельної бази, відповідно до тематики: культурноосвітні пріоритети іммігрантів-українців; проблеми початкового й середнього шкільництва як основи загальноосвітньої та майбутньої фрахової підготовки української молоді; організація та зміст діяльності українських закладів із фрахового вишколу молоді; популяризація досягнень українських «прооресіоналістів», передовсім студентів і випускників закладів вищої освіти. Уведено до широкого наукового обігу публікації перших представників українськоі релігійної і світської інтелігенції в державах нового поселення українців-емігрантів, зокрема І. Волянського, Г. Грушки, Н. Дмитріва, С. Думи, С. Кизими, І. Констанкевича, Л. Мишуги, Л. Рожанського, В. Сіменовича, опубліковані на сторінках українських часописів США й Канади.

Акцентовано на унікальності досвіду українців-емігрантів першої хвилі у творенні національного освітнього простору як підгрунтя професійної підготовки молоді, їх ролі в справі поширення серед світового українства рідномовної освіти, професійної підготовки та патріотичного виховання. Наголошено на можливості використання цього досвіду в сучасній освітній практиці, зважаючи на новітні хвилі української еміграції та сочіально-політичні світові прочеси.

Ключові слова: еміграція, діаспора, історіографрія, джерельна база, профеесійна підготовка.

The article provides a historiographical analysis of the issue of vocational training of young people of the first wave of Ukrainian emigration in the context of the development of Ukrainian schooling in the late nineteenth - early twentieth century., Investigated and systematized the source base of this period.

Based on primary sources and periodicals of potential settlements of Ukrainian emigrants, scientific investigations of Ukrainian and Ukrainian diaspora scientists, the content of research, scientific literature, primary sources on the first wave of Ukrainian emigration in the context of established chronology, territorial boundaries, degree of disclosure in the source and Ukrainian abroad

The content of materials of periodicals of the first decade sof the $X X$ century, which are an important part of the source base, is divided according to the following topics: cultural and educational priorities of Ukrainian immigrants; problems of primary and secondary schooling as a basis for general education and future professional training of Ukrainian youth; organization and content of activities of Ukrainian institutions for professional training of youth; popularization of achievements of Ukrainian "professionals", first of all students and graduates of higher education institutions. The publications of the first representatives of the Ukrainian religious and secular intelligentsia in the states of the new settlement of Ukrainian emigrants, in particular, I. Volyansky, G. Hrushka, N. Dmytriv, S. Duma, S. Kyzyma, I. Konstankevich, L. Myshuga, were introduced into wide scientific circulation. L. Rozhansky, V. Simenovych, published in Ukrainian magazines in the USA and Canada. The educational context of the functioning of Ukrainian institutions and coverage of their activities in Ukrainian periodicals of the USA Canada, Western Ukraine, works of journalists of the leading Ukrainian newspapers of the world "Svoboda" (USA), "Ukrainskyj Golos" (Canada), "Dilo" (Lviv), which created, along with other magazines, the national cultural and educational space of the late nineteenth - early twentieth century.

Emphasis is placed on the uniqueness of the experience of Ukrainian emigrants of the first wave in the creation of the national educational space as a basis for vocational training of young people, their role in spreading native Ukrainian language education, vocational training and patriotic education. Emphasis is placed on the possibility of using this experience in modern educational practice, given the latest waves of Ukrainian emigration and socio-political world processes.

Key words: emigration, diaspora, historiography, source base, professional training.
Прикарпатського національного університету імені Василя Стефраника блему глибокого й усебічного вивчення досвіду відбору, змісту, організаційних форм і методів цієї роботи в середовищі української діаспори, передовсім західної, яка була й залишається невід'ємним складником історії українського народу. ним станом розвитку цивілізації, актуалізує про- 
На всіх етапах еволюції української діаспори провідними чинниками освітньої та педагогічнопрофресійної зорієнтованості закордонних українців були освітня політика держав нового громадянства та їхні освітньо-виховні традиції й пріоритети, прагнення до «безболісного» входження дітей і молоді в чинне соціально-економічне, політичне й культурне середовище, водночас потреба фрормування української еліти, збереження національної ідентичності поколінь українців, народжених поза межами України, віра в можливість бути корисними для майбутньої незалежної української держави та підготовка до цієї місії.

Так як питання історіографії профресійної підготовки української молоді першої хвилі еміграції як передумови формування української діаспори $€$ вкрай важливим аспектом дослідження їі досвіду та відгуком на перелічені вище стратегічні напрями сучасності, його актуальність $€$ безсумнівною.

Аналіз останніх досліджень і публікацій. Загальна характеристика розвитку освіти в діаспорі представлена в працях М. Євтуха, В. Качкана, П. Кононенка, Т. Усатенка, Г. Філіпчука. Проблемам становлення й розвитку національної школи в державах масового осідку українців-емігрантів присвячені докторські дисертації В. Кеміня, С. Пономаревського, С. Романюк, І. Руснака; кандидатські - Т. Бублик, Д. Бурім, О. Вагіної, С. Віднянського, Ю. Заячук, А. Онкович та ін. Важливий інформаційний матеріал, дотичний до теми дослідження, містять науково-довідкові та енциклопедичні видання кінця XX - початку XXI ст., авторами чи упорядниками яких $\in$ Т. Боряк, І. Винниченко, О. Вішка, В. Воронін, С. Дроздовський, В. Євтух, Ф. Заставний, С. Лазебник, Б. Лановик, В. Лозицький, О. Малиновська, А. Попок, В. Просалова, М. Савка, Г. Саган, Р. Симоненко, В. Трощинський, А. Шевченко, А. Шлепаков та ін.

Виділення не вирішених раніше частин загальної проблеми. Утім якщо провідні тенденції у становленні та розвитку системи професійної освіти в Україні, концептуальні засади їі розбудови й реформування в умовах української незалежності уже представлені у фундаментальному науково-педагогічному доробку (праці І. Волощука, С. Гончаренка, О. Дубасенюк, В. Кременя, Л. Лук'янової, О. Матвієнко, Н. Ничкало, В. Олійника, Ю. Пелеха, В. Радкевич, О. Щербак та ін.), то комплексний аналіз історіографії організаційнотеоретичних основ і практики професійної підготовки молоді першої хвилі української еміграції не здійснений.

Зважаючи на багатоплановість досліджуваної проблеми й обмеженість у часі, мету статті означуємо як з'ясування сутності сукупності досліджень, наукової літератури, присвячених першій хвилі української еміграції, що аналізуємо за кількома параметрами: за усталеною хроно- логією (кінець XIX - перша половина XX ст.), за територіальними межами, за ступенем розкриття в джерелах «материкової» України й українського зарубіжжя.

Виклад основного матеріалу. Початки інформування «старого краю» про причини й обставини масового виїзду, умови життя й адаптації українців у чужому багатоетнічному середовищі та перші спроби їхньої культурно-освітньої діяльності пов'язуємо з кінцем XIX ст. і співвідносимо передовсім 3 американським континентом. Вони представлені публікаціями (дописи, «звістки», «письма», передруки з перших українських газет у США) у тодішній пресі східної та західної частин України (як київська «Рада», львівські «Діло», «Літературно-науковий вісник», «Народ», «Руслан», чернівецька «Буковина» тощо), що виявилася найбільш поширеним і популярним масовим джерелом інформації до появи окремих аналітичних оглядів і наукових розвідок, зокрема й із теми дослідження.

Матеріали періодичних видань перших десятиліть XX ст., дотичні до об'єкта і предмета наукового дослідження, можна умовно поділити на декілька груп:

а) культурно-освітні пріоритети іммігрантівукраїнців;

б) проблеми початкового й середнього шкільництва як основи загальноосвітньої та майбутньої фрахової підготовки української молоді;

в) організація та зміст діяльності українських закладів із фрахового вишколу молоді;

г) популяризація досягнень українських «профресіоналістів», передовсім студентів і випускників закладів вищої освіти.

Авторами цих матеріалів були, як правило, перші представники української релігійної і світської інтелігенції в державах Північної та Південної Америки. Зокрема, у США ним став І. Волянський: упродовж 1884-1889 рр. газета «Діло» в рубриках «Новинки» й «Дописи» вмістила 4 повідомлення про особливості його виїзду до цієї країни для «душпастирської» праці; 17 - про зміст «священичої» та громадсько-культурної діяльності в середовищі американських українців і 5 авторських публікацій, серед яких - витяг із листа до редакції про запланування відкриття в місцевості Шенандоа (Пенсільванія) друкарні та першої української елементарної школи [15, с. 3].

Священик Львівської єпархії Н. Дмитрів, скерований для організації релігійного життя українців спочатку в США, а в 1897 р. - у Канаді, у листах і дописах до «Діла» представив галицьким читачам стан українських громад у другій половині 1890-х рр. (більше ніж 15 публікацій), а також одним із перших узагальнив «здобутки русинів» на «поли церковнім», почасти культурно-освітньому, за 15 років їхнього перебування в Пів- 
нічній Америці (від 1884 до 1899 рр.) [13, с. 1-2; 20, т. 3, c. 348-349].

Один із перших українських священиків у бразильській Парані С. Кизима інфоормував у «Ділі» про релігійне й культурно-освітне життя українців у Бразилії [16, с. 1-2], а в 1901 р. ця ж газета опублікувала відомості про заснування його заходами народної школи з українською та польською мовами навчання в Прудентополісі $[17$, с. 3].

Наприкінці XIX ст. в «Ділі» з'явилися дев'ять публікацій галицького громадського діяча й економіста Л. Рожанського (псевд. і крипт. Любомир Гнатович, Суходольський, Л. Гн. Р-скій та ін.), у яких, крім проблем виїзду галичан до Бразилії [9; 21], він наголошував на необхідності направити туди українських священиків і вчителів, одним із перших актуалізував проблему освіти українців-емігрантів на зборах товариства «Просвіта» у Львові [8, c. 1-210, c. 2-3].

У 1890-х рр. редакція «Діла» публікує листи представника нечисленної світської української інтелігенції у США, свого «платного» кореспондента В. Сіменовича, який прибув на американський континент зі Східної Галичини в 1887 р. й того ж року очолив редакцію заснованого І. Волянським першого українського тижневика «Америка». Закінчивши медичні студії в Чикаго (1892р.) і доповнивши їх у Парижі, він став одним із провідних українських громадсько-культурних діячів у США. Крім відомостей про «відносини Русинів» у цій країні, В. Сіменович інфоормував земляків-галичан про початки «організованого руху» в середовищі українців-іммігрантів [27, с. 2; 28, с. 1-2].

Тенденцію зростання уваги «Діла» до проблем українських переселенців засвідчують публікації початку XX ст. Поряд із традиційними редакційними рубриками («Вісті з Америки», «Новинки», «Дописи»), спробами більш глибокого аналізу позитивних і негативних «вислідів» еміграції, узагальнень її кількісних показників на сторінках газети побачили світ авторські публікації як уже згадуваних представників української імміграції (Н. Дмитрів, В. Сіменович), так і нових переселенців, а також західноукраїнських релігійних і культурно-освітніх діячів (О. Волянського, Г. Грушки, С. Думи, І. Констанкевича). У них (хоч здебільшого епізодично) представлені проблеми не лише загальної освіти, а й професійної підготовки молоді.

3 появою українських періодичних видань на американському континенті проблеми переселенців, їхні нагальні потреби найвиразніше окреслює одна 3 найстаріших українських газет у діаспорі «Свобода» (США, із 1893 р.), яка аж до виникнення рідномовної преси в інших державах Північної й Південної Америки обслуговувала інтереси українців-іммігрантів і в цих країнах. За твердженням визначного громадсько-політичного діяча Західної
України, представника уряду ЗУНР у США й редактора багатьох видань у діаспорі Л. Мишуги, «Свобода» постала «з любови до рідної мови, віри й традиції, з прив'язання українського іміґранта до своєї бідної землі», залишаючись упродовж XX ст. «учителем і провідником» американських українців [31, с. 6-7].

Окреслюючи змістові «напрямні» публікацій «Свободи», педагог і громадсько-культурний діяч у Галичині, іï багаторічний співробітник, а згодом політичний емігрант Л. Ясінчук зазначав, що наприкінці XIX - на початку XX ст. вона змальовувала «яркі картини імігрантського лихоліття, незбагнутого туску (туги, суму - О. Дж.), початкових злиднів...», водночас «заторкувала» справи, які «ворушать серце й мозок кожного українця мова, організація, школа, правопис, наука ... великі люди ...» [33, с. 62].

Визначивши головним завданням просвіту українців-іммігрантів як підстав їхнього цивілізаційного поступу й зростання добробуту («Браття Русини!» $[3$, с. 1]) й обравши на межі XIX-XX ст. вихідними постулатами гасла «Від виховання молодого покоління залежить доля народу»; «Треба посилати дітей до англійських шкіл, але, крім того, закладати школи української мови»; «Американські українці мусять витворити інтелігенцію з-поміж себе», «Свобода» в численних публікаціях привертала увагу українського загалу до питань про важливість освіти рідною мовою, відкриття українських шкіл і читалень у США; про участь у цій справі українських священиків, учителів та українських родин, закликаючи останніх учити дітей розмовляти рідною мовою, «запалити вогонь любови» до рідної землі, готовності до боротьби за її волю $[14$, с. 2; 22; 23]. Крім того, газета активно популяризувала ухвали перших з'їздів українських священиків (1899, 1901 рр.), матеріали народних віч (1900, 1905 рр.), особливо просвітного віча 1909 р. у Філадельфрії, які стосувалися розвитку українських шкіл і позашкільних інституцій (елементарні для дітей молодшого шкільного віку, вечірні для дорослих, курси анальфрабетів, фрахові курси, бурси, читальні, просвітні товариства), обґрунтовували необхідність підвищення кваліфікації та консолідації учительських «сил» [6, с. 1; 26, с. 330-332].

Проте найбільш яскраво загальноосвітній і професійно-педагогічний континуум публікацій преси українського зарубіжжя початкового періоду заокеанської еміграції простежується в матеріалах тижневика «Український голос» (Канада, з 1910 р.).

Уже в його першому номері міститься своєрідний дороговказ для українців у Канаді початку XX ст.: поряд із необхідністю продовжити, як і раніше, «клопотатись про ... матеріальне забезпеченє» варто «просвічуватись» (виокр. - О. Дж.) і ... ставати разом до діла...» [7, т. 1, с. 7 ; 25]. 
Здійснений детальний аналіз публікацій «Українського голосу» перших десятиліть його фрункціонування дав змогу виявити їх основні змістові домінанти, серед яких:

- важливість освіти молодого українського покоління як підґрунтя для його успішного «входження» в чужоетнічне середовище й осягнення гідного місця в полікультурному оточенні;

- спонукання українських родин до забезпечення обов'язкових державних англомовних студій дітей і молоді та навчання в українських закладах освіти;

- інфрормування читачів про перші кроки українських громад у Канаді на полі елементарної шкільної освіти й фрахового вишколу молоді;

- «конечність» вищої освіти як умови опанування «ліпших профресій, фрахів, ремесел» $[1$, с. 4];

- підготовка й підвищення кваліфікації українських учителів;

- потреба освіти й патріотичного виховання дівчат - майбутніх українських матерів;

- успіхи перших українців-студентів фрахових шкіл та університетів Канади;

- діяльність перших українських молодіжних та учительських організацій у цій державі тощо.

Варто зазначити, що саме на сторінках «Свободи» й канадського «Українського голосу» вже перед Першою світовою війною зустрічаються такі дефініції, як «українські професіоналісти», «українські фрахівці».

Центрально-західноєвропейський контекст аналізованої наукової проблеми кінця першої хвилі української еміграції започатковують матеріали українських періодичних видань, передовсім календарів товариства «Просвіта» у Львові за 1915-1918 рр. й ілюстрованого місячника «Літопис Червоної Калини» (Львів, 1925-1939рр.). Показовими в контексті теми наукового пошуку є статті на їх сторінках визначних громадсько-політичних та освітніх діячів Західної України: С. Барана [2, с. 164-175], Н. Даниша [12, с. 265-274], С. Годованого $[11$, с. $11-14 ; 18-19]$, Й. Іванця $[18$, с. 6-8, 15-18], В. Пастущина [13-16; 16-19; 24, с. 9-11], І. Чепиги [29, с. $178-184 ; 30$, с. 184-191], які розкривають особливості культурно-освітнього життя українських виселенців на австрійських, польських і чеських теренах у роки Першої світової війни. Оперті на реальних фрактах і даних, ілюстровані документальними фоотографріями й матеріалами, вони в сукупності становлять багатий джерельний масив дослідження.

На початок XX ст. припадають спроби узагальнення відомостей про західну, насамперед заокеанську українську еміграцію, і про ії громадськокультурну й освітню діяльність в окремих працях. Першим серед представників материкової України, хто взявся «основніше досліджувати українську імміґрацію» [4, с. 5; 26, с. 456], був Ю. Бачинський.
Його праця «Українська іміґрація в З'єднаних державах Америки» $є$ найповнішим джерелом і для характеристики культурно-освітнього життя українських переселенців у США наприкінці XIX - на початку XX ст.

Уперше в українській літературі такого змісту в ній виокремлено підрозділ «Школи», у якому увиразнено потребу українських парафріяльних шкіл у США, простежено розвиток їх мережі у 1893-1904 рр., почасти схарактеризовано зміст навчання, його дидактично-методичне забезпечення, розкрито діяльність освіченої частини імміграції в галузі освіти дітей і молоді та просвіти серед дорослих.

На підставі викладеного погоджуємося з висновком українського історика у США Л. Винара про значення праці Ю. Бачинського, зробленим у 1971 р.: попри вузьку джерельну базу, її автор «дав нам першу історію й соціологічну студію української іміґрації ... описав багатовимірне життя української громади в Америці в ії ранніх роках побуту» $[4$, с. 12, 16].

Якщо праця Ю. Бачинського базувалася здебільшого на матеріалах офріційної статистики й преси США кінця XIX - початку XX ст. та власних спостереженнях, то 3. Кузеля в основу своєї наукової хроніки «Причинки до студій над нашою еміґрацією», уміщеної в Записках НТШ у Львові в 1911-1912 pp. (T. 101 (CL), c. 144-158; T. 105 (CV), с. 175-204, Т. 107 (CVII), с. 129-163), поклав наукові студії тодішніх зарубіжних, передовсім німецьких і польських, дослідників історії світової еміграції загалом і Австро-Угорської імперії зокрема: Л. Каро (L. Caro), Й. Конрада (J. Conrad), Р. Прлліґля (R. Pfligl), К. Ріттера (K. Ritter), Л. Сарторінса (A. Sartorins), Е. Шульца (Е. Shultze) та ін. Базуючись на вміщених у них даних, 3. Кузеля не тільки показав рух «австро-угорської» української еміграції до держав Північної й Південної Америки у 1900-1909 рр., а й подав відомості про ії структуру та регіональні особливості порівняно 3 іншими народами Австро-Угорської імперії, уперше в українській науковій думці вмістив статистику грамотності українських переселенців, еволюцію роду їхніх занять у місцях нового осідку (T. CV, c. 149; T. CVII, c. 147).

У 1916 р. у Відні вийшла друком праця О. Кириленка «Українці в Америці», метою якої автор визначив інформування «широких кругів читачів старого краю ... про долю ... наших земляків на ... їх прибраній вітчині», «... про життє й побут, сучасність і будучність заморських Українців...» $[19$, с. 3]. Поряд із оглядом обставин життя, особливостями й умовами праці перших українців-іммігрантів у США й Канаді автор аналізує початки культурно-освітньої праці, складниками якої визначає шкільництво, видавничий і пресовий («часописний») рухи, діяльність «запомогових» товариств, 
читалень, братств тощо. Як і Ю. Бачинський та 3. Кузеля, головним об'єднуючим чинником української імміграції він уважає церкву [19, с. 13].

Одним із перших О. Кириленко фріксує специфріку професії вчителя в Канаді як «переходової»: «... ледви котрий учитель учителює довше ніж чотири, п'ять літ, доки не вмотаєть ся в якийсь інтерес», через що відчувається брак освічених і «добре вишколених» педагогів [19, с. 21].

Чи не найважливішою умовою підвищення есрективності культурно-освітнього життя українців-іммігрантів уже перед першою світовою війною автор аналізованої праці визначив необхідність заснування «всеобіймаючих культурних, політичних і економічних орґанізацій і товариств», метою яких було б «загальне порозумінє, залученє сил до спільної праці й поставлення дороговказу на будучність у культурній, політичній і економічній роботі серед наших земляків у Північній Америці» $[19$, c. $30-32]$.

Для дослідження важливими є також думки про необхідність протидії впливам чужої «вищої культури, окруження ... школи» саме серед молоді 15-20 років, яка виявляє найбільший нахил «цурати ся власного народу й зачисляти себе до другого ... що переважає чисельно й панує» $[19$, c. 34-35].

Проте загалом аналізована праця, що не опирається на джерельну базу, відповідає своїй меті як інсоормаційно-популярна студія. У ній, аналогічно до інших окремих праць і публікацій у періодичних виданнях перших десятиліть XX ст., постановка проблеми профресійної підготовки молоді $\epsilon$ схематичною, без визначення конкретних шляхів і способів її розв'язання.

Висновки. Підсумовуючи аналіз джерельної бази професійної підготовки молоді першої хвилі української еміграції, зауважимо, що іїі історіографрію фрормують теоретико-методологічні напрацювання в галузі освіти вітчизняних і зарубіжних науковців, фрундаментальні розвідки української діаспори, творча спадщина освітніх діячів і педагогів - репрезентантів західної української діаспори XX ст., статті в науково-довідкових та енциклопедичних виданнях, зарубіжна мемуаристика.

3'ясування їх сутності дає змогу констатувати, що питання про просресійну підготовку молоді в рамках першої хвилі масової української еміграції розглядалися в контексті соціально-економічних потреб і загальнокультурних процесів у середовищі українців-емігрантів та обмежувалися здебільшого їх порушенням на сторінках рідномовних періодичних видань Західної України та Північної Америки, почасти в окремих працях видатних представників українства кінця XIX - першої половин XX ст.

Перспективним уважаємо аналіз джерельної бази в межах наступних «хвиль» масового пере- селення українців до держав Заходу, що дасть змогу виокремити найяскравіші зразки інформації, дотичної до об'єкта і предмета дослідження, від невідомих публікацій у періодичних виданнях України й української діаспори, спогадової літератури й епістолярію до фрундаментальних наукових досліджень історичного, соціологічного, культурологічного змісту й діаспорної архівістики.

\section{БІБЛІОГРАФІЧНИЙ СПИСОК:}

1. Апель в справі вищої освіти для української молоді в Канаді. Український голос. 1919. Ч. 30.

2. Баран С. Австрийські Українці на воєнній еміграції у Відні в рр. 1914/5. Ілюстрований народний календар «Просвіта» 3 термінаром на переступний рік 1916. Львів : Коштом Товариства «Просвіта», 1916. C. $164-175$.

3. Браття Русини! Свобода, 1893. Ч. 1. С. 1.

4. Винар Л. Юліян Бачинський - видатний дослідник української еміграції. Мюнхен - Нью-Йорк : Українське Історичне Товариство. Серія: Історичні студії, 1971. Ч. 8. $16 \mathrm{c.}$

5. Винницька І. Діяспора - це окремий організм. Свобода. 1996. Ч. 117. С. 2; Ч. 118. С. 2-3.

6. Відозва до українського громадянства. Прага : Управа «Допомогового Фонду Української Університетської Освіти», 1935. 4 с.

7. Войценко О. Літопис українського життя в Канаді : у 6 т. Едмонтон : Накладом і друком Видавничої Спілки «Тризуб», 1961-1982. Т. 1. 296 с.; Т. 2. 395 c.; T. 3. 307 c.; T. 4.477 c.; T. 5.468 c.; T. 6.416 c.

8. Гнатовичъ Л. Въ интересь Русиновъ въ Бразиліи. Дъло. 1896. Ч. 10. С. 1-2.

9. Гнатович Л. Въ справь еміґраціи нашихъ селянъ до Бразиліи. Дъло. 1895. Ч. 54. С. 2; Ч. 55. С. 2 ; Ч. 56. С. 2 ; Ч. 58. С. 2 ; Ч. 61 . С. 2 ; Ч. 66. С. $1-2$; 4. 70. С. 2 ; Ч. 71-72. С. 2.

10. Гнатович Л. До Бразиліи треба рускихъ священиковъ и учительвъ. Дъло. 1895. Ч. 235. C. 2-3.

11. Годований С. Освітня справа в українських таборах для інтернованих в Дайч-ґаблю. Ілюстрований журнал історії та побуту «Літопис Червоної Калини». Львів, 1931. Ч. 1. С. 18-19.

12. Даниш Н. Наше шкільництво на еміграції у Відні (1914-1917). Ілюстрований народний календар товариства «Просвіта» на рік 1918. Львів, 1917. C. $262-274$.

13. Дмитров Н. Здобутки Русиновъ въ Америце на поли церковномъ за 15 летъ. Діло. 1899. Ч. 156. C. $1-2$.

14. Другий Світовий Конґрес Вільних Українців. Матеріяли / за ред. І. Базарко та ін. Торонто - НьюЙорк - Лондон : Видання Секретаріяту Світового Конґресу Вільних Українців, 1986. 470 с.

15. Зъ Шенандоа въ Америце. Діло. 1886. Ч. 64. C. 3.

16. Зъ житя Русиновъ въ обохъ Америкахъ въ Канаде и въ Бразиліи. Діло. 1898. Ч. 88. С. 1-2.

17. Зъ бразилійскои Параны. Діло. 1901. Ч. 13. C. 3.

18. Іванець Й. Літопис Червоної Калини. 1934. 4. 10-12. C. 3-8. 
19. Кириленко О. Українці в Америці. Відень : Накладом «Союза визволення України», 1916. 42 с.

20. Курилишин К. Часопис «Діло» (Львів, 1880-1939 рр.) : матеріали до біобібліографістики / НАН України, Львівська національна наукова бібліотека ім. В. Стефраника. Дрогобич : Коло, 2015. T. 1 : 1880-1889 pp. 640 с.; 2016. Т. 2: 1890-1894 pp. 608 с.; 2017. T. 3: 1895-1899 pp. 712 с.; 2018. T. 4: 1900-1904 pp. 824 c.; 2019. T. 5: 1905-1909 pp. 768 c.

21. Л. Гн. Р-скій. Пересторога для еміґрантовъ. Дъло. 1895. Ч. 239. С. 1.

22. Ми жиєм. Свобода. 1894. Ч. 12.

23. Нам треба школи. Свобода. 1894. Ч. 5.

24. Пастущин В. Український табор сиріт і старців в Святобожицях (1917-1920). Ілюстрований журнал історії та побуту «Літопис Червоної Калини». Львів, 1935. Ч. 9. С. 9-11; 1935. Ч. 10. С. 13-16; 1935. Ч. 11. С. $16-19$.

25. Прокоп Д. Українці в Західній Канаді. До історії поселення та поступу. Едмонтон-Вінніпеґ, 1987. 548 с.

26. Пропам'ятна книга. Видана 3 нагоди сороклітнього ювилею Українського Народного Союзу / зред.
Л. Мишуга. Джерзі Ситі, Ню Джерзі : Накладом Українського Народного Союзу, 1936. 752 с.

27. Сіменовичъ. Письмо зъ Америки. Діло. 1894. 4. 54. C. 2.

28. Сіменовичъ. Письма з Чікаго. Діло. 1897. 4. 38. C. 1-2.

29. Чепига І. Українське шкільництво на еміґраці Український ілюстрований календар Товариства «Просвіта» 3 термінаром і літературно-науковим збірником на звичайний рік 1917. Львів : Коштом Товариства «Просвіта». 1917. С. 184-191.

30. Чепига І. Українське шкільництво на еміґраці Український ілюстрований календар Товариства «Просвіта» 3 термінаром і літературно-науковим збірником на звичайний рік 1917. Львів : Коштом Товариства «Просвіта», 1917. С. 184-191.

31. Ювілейний альманах «Свободи»: 1893-1953 / зред. Л. Мишуга і А. Драган. Джерзі Ситі : Вид. Українського Народного Союзу, б. р. 248 с.

32. Ясінчук Л. Школа й молодь в Америці. Рідна школа. 1933. Ч. 18. С. 291; Ч. 19. С. 306-307; Ч. 20. C. 320-323. 